\title{
Emendation of the genus Acidomonas Urakami, Tamaoka, Suzuki and Komagata 1989
}

Correspondence

Tai Uchimura

tai@nodai.ac.jp
Shun-ichi Yamashita, Tai Uchimura and Kazuo Komagata

Department of Applied Biology and Chemistry, Faculty of Applied Bioscience, Tokyo University of Agriculture, Sakuragaoka 1-1-1, Setagaya-ku, Tokyo 156-8502, Japan

The genus Acidomonas and the species Acidomonas methanolica were recharacterized by using the type strain (NRIC $0498^{\top}$ ), three reference strains and 10 methanol-utilizing bacteria that were isolated from activated sludge from three different sewage-treatment plants in Tokyo. Based on 16S rDNA sequences, all strains formed a single cluster within the Acetobacteraceae that was clearly different from the genera Acetobacter, Gluconobacter, Gluconacetobacter, Asaia and Kozakia. The 14 strains were identified as a single species, Acidomonas methanolica, by DNA-DNA similarities, showed DNA G+C contents that ranged from 62 to $63 \mathrm{~mol} \%$ and had Q-10 as the major quinone, accounting for $>87 \%$ of total ubiquinones. Cells of Acidomonas methanolica had a single polar flagellum (or occasionally polar tuft flagella); this differs from a previous study that described peritrichous flagella. Oxidation of acetate was positive for all strains, but oxidation of lactate was weakly positive and varied with strains. Dihydroxyacetone was not produced from glycerol. Pantothenic acid was an essential requirement for growth. The strains tested grew at mostly the same extent at $\mathrm{pH} 3 \cdot 0-8 \cdot 0$. Therefore, Acidomonas methanolica should be regarded as acidotolerant, not acidophilic. The descriptions of the genus Acidomonas and the species Acidomonas methanolica Urakami, Tamaoka, Suzuki and Komagata 1989 are emended with newly obtained data.
The genus name Acidomonas was validly published for acidophilic, methanol-utilizing bacteria (Urakami et al., 1989), incorporating Acetobacter methanolicus Uhlig et al. 1986. Acidomonas methanolica is the type and only species reported so far in this genus. Members of the genus Acidomonas are recognized as methanol-utilizing bacteria (Bulygina et al., 1990, 1992; Komagata, 1990; Bulygina et al., 1993; Green, 1993). In fact, strain BNS-25 (an acidophilic, methanol-utilizing bacterium) was once regarded as a promising tool for the production of single-cell proteins (SCPs) from methanol (Urakami et al., 1981). This strain was later identified as a member of Acidomonas methanolica (Urakami et al., 1985, 1989). On the other hand, the phylogenetic relationship of the genus Acidomonas to acetic acid bacteria (the family Acetobacteraceae) was first suggested by $5 \mathrm{~S}$ rRNA sequencing (Bulygina et al., 1992). This finding was confirmed by $16 \mathrm{~S}$ rDNA sequences (Yamada et al., 1997; Boesch et al., 1998). The revival of

Published online ahead of print on 19 December 2003 as DOI 10.1099/ijs.0.02946-0.

Abbreviation: SCP, single-cell protein.

The GenBank/EMBL/DDBJ accession numbers for the 16S rDNA sequences of Acidomonas methanolica NRIC 0498 ${ }^{\top}$, LMG 1667, LMG 1669, LMG 1735, TS 0101, TS 0114, TS 0117, TS 0121, TS 0128, TS 0131, TS 0135, TS 0143, TS 0145 and TS 0156 are AB110702AB110715, respectively.
Acetobacter methanolicus was once proposed (Sievers et al., 1994), but another study justified the description of the genus Acidomonas (Yamada et al., 2000). However, since the work of Uhlig et al. (1986) and Urakami et al. (1989), few Acidomonas strains have been isolated until now. In addition, this taxon is problematic, as some characteristics differ in the descriptions by Uhlig et al. (1986) and Urakami et al. (1989) and only four Acidomonas methanolica strains are available from culture collections worldwide. They are the type strain NRIC $0498^{\mathrm{T}}\left(=\right.$ DSM $5432^{\mathrm{T}}=\mathrm{JCM} 6891^{\mathrm{T}}=$ LMG $1668^{\mathrm{T}}=\mathrm{MB5}^{\mathrm{T}}$ ) (Steudel et al., 1980; Uhlig et al., 1986), LMG 1667, LMG 1669 and LMG 1735. The type strain was isolated from an unsterilized process of SCP production from methanol with Candida sp. and LMG 1735 was isolated from Saccharum officinarum (Janssens et al., 1998). This low number of strains is not enough to verify the diversity of the species.

The present study aims to isolate novel Acidomonas strains from activated sludge samples of sewage-treatment plants and to recharacterize and emend the genus Acidomonas by using newly obtained 16S rDNA sequences, DNA-DNA similarities, quinone systems and phenotypic characteristics of the new isolates and strains that were obtained from culture collections.

The enrichment culture approach was employed for the isolation of Acidomonas strains by using medium $\mathrm{C}$ 
(Urakami et al., 1985) at $\mathrm{pH} 4.0$ and $30^{\circ} \mathrm{C}$. Medium C contained $\left(1^{-1}\right): 10 \mathrm{ml}$ methanol, $0 \cdot 2 \mathrm{~g}$ yeast extract, $3 \cdot 0 \mathrm{~g}$ $\left(\mathrm{NH}_{4}\right)_{2} \mathrm{SO}_{4}, 4.0 \mathrm{~g} \mathrm{KH}_{2} \mathrm{PO}_{4}, 0 \cdot 2 \mathrm{~g} \mathrm{MgSO}_{4} .7 \mathrm{H}_{2} \mathrm{O}, 30 \mathrm{mg}$ $\mathrm{CaCl}_{2} \cdot 2 \mathrm{H}_{2} \mathrm{O}, 5 \cdot 0 \mathrm{mg} \mathrm{MnCl}_{2} \cdot 4 \mathrm{H}_{2} \mathrm{O}, 5 \cdot 0 \mathrm{mg} \mathrm{ZnSO} \cdot 7 \mathrm{H}_{2} \mathrm{O}$, $0.5 \mathrm{mg} \mathrm{CuSO}{ }_{4} \cdot 5 \mathrm{H}_{2} \mathrm{O}$ and $1.0 \mathrm{ml}$ vitamin solution $(\mathrm{pH} 4 \cdot 0)$. Ferric citrate (present in the original composition) was omitted from the medium used in this study. Vitamin solution contained $\left(\mathrm{l}^{-1}\right): 2 \mathrm{mg}$ biotin, $400 \mathrm{mg}$ calcium pantothenate, $400 \mathrm{mg}$ pyridoxine/ $\mathrm{HCl}, 400 \mathrm{mg}$ thiamin/ $\mathrm{HCl}, 200 \mathrm{mg}$-aminobenzoic acid, $2 \mathrm{mg}$ folic acid, $2 \mathrm{~g}$ inositol, $400 \mathrm{mg}$ nicotinic acid and $200 \mathrm{mg}$ riboflavin. If necessary, $20 \mathrm{~g}$ agar $\mathrm{l}^{-1}$ was added to solidify the medium. Isolation materials were inoculated into medium $\mathrm{C}$ and incubated at $30{ }^{\circ} \mathrm{C}$ with shaking. When microbial growth occurred, cultures were subjected to subsequent enrichment. After repeating enrichment cultures, micro-organisms were streaked on PYMe medium agar plates and any colonies that appeared were transferred to medium $\mathrm{C}$ broth. Microbial growth in the broth was checked microscopically and methanol-utilizing bacteria were isolated and purified by streaking on medium $\mathrm{C}$ agar plates. PYMe medium contained $\left(1^{-1}\right): 10 \mathrm{ml}$ methanol, $5.0 \mathrm{~g}$ peptone and $3.0 \mathrm{~g}$ yeast extract $(\mathrm{pH} 4 \cdot 0)$. PYMe medium was also used for isolation of methanol-utilizing bacteria. This medium was enriched with rather high concentrations of yeast extract and peptone and favoured the isolation of a variety of methanol-utilizing bacteria. Pure cultures of methanolutilizing bacteria were obtained in the same manner as described above. Activated sludge samples were mainly used as isolation sources, followed by vegetables, fruit, decayed woods and leaves, manure, paddy soils etc. Activated sludge samples were obtained at the Ochiai, Morigasaki and Shibaura sewage-treatment plants in Tokyo; 19 activated sludge samples were collected at different sites of the plants. In total, 56 methanol-utilizing bacteria were isolated from the activated sludge samples, but not from other isolation sources. Of the 56 strains, 10 were selected for subsequent study, considering prevention of picking up the same clone, colony appearance, sampling sites and locations of the plants. Strain TS 0101 was isolated from a sample that was collected at the Ochiai plant, strains TS 0114, TS 0117, TS 0121, TS 0128, TS 0131 and TS 0135 were collected at the Morigasaki plant and strains TS 0143 , TS 0145 and TS 0156 were collected at the Shibaura plant. They have been deposited in the NODAI Culture Collection, Tokyo University of Agriculture, Tokyo, Japan (NRIC), with the accession numbers NRIC 0548, NRIC 0549, NRIC 0550, NRIC 0551, NRIC 0552, NRIC 0553, NRIC 0554, NRIC 0555, NRIC 0556 and NRIC 0557, respectively. Including Acidomonas methanolica NRIC $0498^{\mathrm{T}}$, LMG 1667, LMG 1669 and LMG 1735, which were obtained from culture collections, 14 strains were used throughout this study.

Sequencing of $16 \mathrm{~S}$ rDNA was carried out by using previously reported methods (Lisdiyanti et al., 2000; Yamada et al., 2000). 16S rDNA was amplified by PCR with two primers: 20F (5'-GATTTTGATCCTGGCTCAG-3', positions
9-27) and 1500R (5'-GTTACCTTGTTACGACTT-3', positions 1509-1429). Numbering of positions was based on the Escherichia coli numbering system (GenBank accession no. V00348; Brosius et al., 1981). Purified PCR products were sequenced directly by using an ABI PRISM BigDye Terminator Cycle Sequencing Ready Reaction kit and an ABI PRISM model 310 genetic analyser. The following six primers were used: 20F, 1500R, 520F (5'-CAGCAGCCGCGGTAATAC-3', positions 519-536), 520R (5'-GTATTACCGCGGCTGCTG-3', positions 536-519), 920F (5'-AAACTAAATGAATTGACGG-3', positions 907-926) and 920R (5'-CCGTCAATTCATTTGAGTTT-3', positions 926-907).

Multiple alignment was performed by using the program CLUSTAL X (version 1.18) (Thompson et al., 1997). Distance matrices for the aligned sequences were calculated by using the two-parameter method ( $\left.K_{\text {nuc }}\right)$ (Kimura, 1980). The neighbour-joining method was used for constructing a phylogenetic tree (Saitou \& Nei, 1987). Robustness of individual branches was estimated by bootstrapping with 1000 replicates (Felsenstein, 1985). Species, type strains, strain numbers and GenBank accession numbers are presented in Fig. 1.

Acidomonas methanolica NRIC $0498^{\mathrm{T}}, 10$ isolates and three reference strains were subjected to phylogenetic analysis based on 16S rDNA sequences. Similarity values of $16 \mathrm{~S}$ rDNA sequences (on the basis of 1408 bases) of Acidomonas methanolica NRIC $0498^{\mathrm{T}}$ and the new isolates and reference strains were calculated in pairs; similarities among the strains tested were $99 \cdot 9-100 \%$. The above strains formed a single cluster within the Acetobacteraceae (Fig. 1) that was clearly distant from the genera Acetobacter, Gluconobacter, Gluconacetobacter, Asaia and Kozakia.

DNA was extracted and purified by the method of Saito \& Miura (1963). Levels of DNA-DNA similarity were determined by the fluorometric DNA-DNA hybridization method in microdilution wells (Ezaki et al., 1989). A probe was prepared with DNA from Acidomonas methanolica NRIC $0498^{\mathrm{T}}$ and hybridization was carried out at $50^{\circ} \mathrm{C}$. DNA $\mathrm{G}+\mathrm{C}$ contents were determined by reverse-phase HPLC (Tamaoka \& Komagata, 1984).

Levels of DNA-DNA similarity between the type strain of Acidomonas methanolica and the 10 isolates and three reference strains were $76-100 \%$. Thus, all strains tested were identified as Acidomonas methanolica. DNA G $+\mathrm{C}$ contents ranged from 62 to $63 \mathrm{~mol} \%$.

Isoprenoid quinone compositions were determined by HPLC (Komagata \& Suzuki, 1987). Acidomonas methanolica NRIC $0498^{\mathrm{T}}$, the 10 isolates and the three reference strains contained ubiquinones, with Q-10 accounting for $>87 \%$ and Q-9 for $<11 \%$ of the total ubiquinones.

Phenotypic characteristics were examined by using previously described methods (Asai et al., 1964; Lisdiyanti et al., 2000) unless otherwise stated. PYM medium 


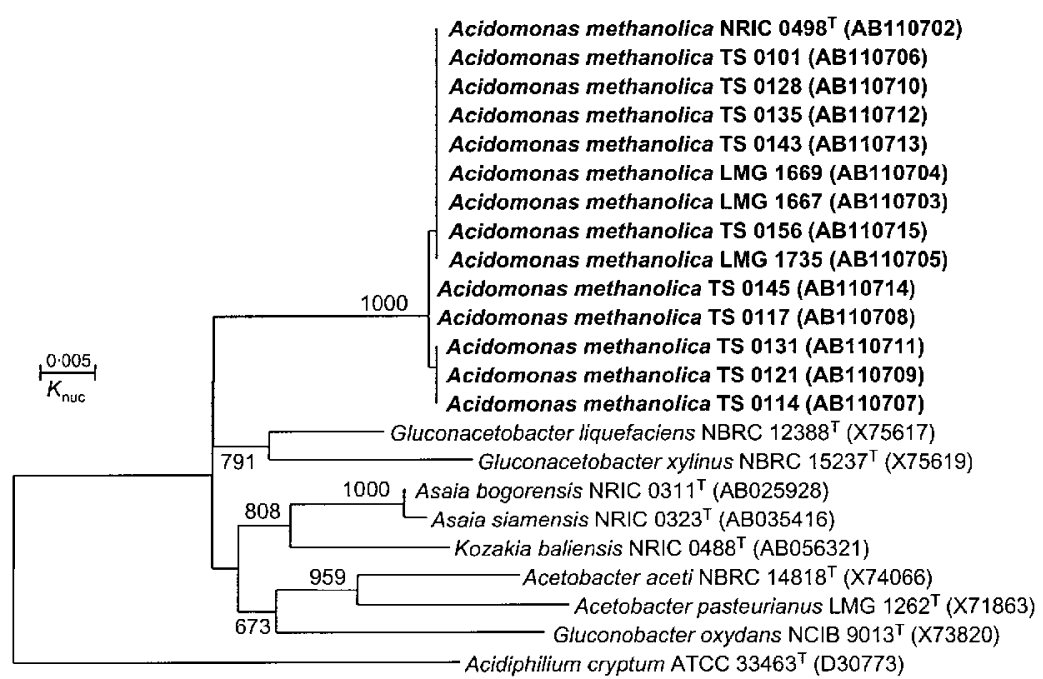

Fig. 1. Phylogenetic relationships of Acidomonas methanolica and other acetic acid bacteria, deduced from $16 \mathrm{~S}$ rDNA sequences. Acidophilium cryptum ATCC $33463^{\top}$ was used as the outgroup. Numbers at nodes represent bootstrap values (1000 replicates). Bar, $0.005 K_{\text {nuc }}$.
(Urakami et al., 1989), which contained $\left(1^{-1}\right): 10$ g glucose, $5 \mathrm{~g}$ peptone, 3 g yeast extract and $3 \mathrm{~g}$ malt extract ( $\mathrm{pH} 6 \cdot 0$ ), was used as a basal medium and strains were cultivated at $30{ }^{\circ} \mathrm{C}$. Motility was examined by the hanging-drop method. PYM medium and modified PYM medium, in which glucose was replaced by methanol, were used for examining motility and were incubated at 25 and $30^{\circ} \mathrm{C}$. Oxidation of acetate to $\mathrm{CO}_{2}$ and $\mathrm{H}_{2} \mathrm{O}$ was examined by the method of Leifson (1954) and oxidation of lactate was determined by the methods of Leifson (1954) and Shimwell et al. (1960). Urease was examined by using the medium of Christensen (1946). Requirement of pantothenic acid was determined by using medium $C$ from which yeast extract was omitted. Several passages through this medium were needed to prevent carry-over of growth factors from inocula. Assimilation of carbon compounds was also investigated by using yeast extract-omitted medium C. Growth in the presence of $30 \%$ glucose was detected by using a medium that contained $\left(1^{-1}\right): 300$ g glucose, 5 g peptone, 3 g yeast extract and $3 \mathrm{~g}$ malt extract. Production of gluconic and ketogluconic acids was examined by using a medium that contained $\left(1^{-1}\right)$ : 30 g glucose and 3 g yeast extract $(\mathrm{pH} 6 \cdot 8)$; products were determined by HPLC. Growth in the presence of $0.35 \%$ acetic acid was examined by using a medium that contained $\left(\mathrm{l}^{-1}\right)$ : 10 g glucose, 5 g peptone, $3 \mathrm{~g}$ yeast extract, $3 \mathrm{~g}$ malt extract and $3.5 \mathrm{~g}$ acetic acid.

Cells were Gram-negative and rod-shaped, measuring $0 \cdot 5-$ $0 \cdot 8 \times 1 \cdot 5-2 \cdot 0 \mu \mathrm{m}$. Of the 14 strains tested, only five showed motility. Cells that were cultivated on glucose at $25^{\circ} \mathrm{C}$ were more actively motile than those that were cultivated on methanol and incubated at $30^{\circ} \mathrm{C}$. Strains LMG 1667, LMG 1669, TS 0101, TS 0131 and TS 0156 showed motility when cultivated on glucose at $25^{\circ} \mathrm{C}$. Cells that were incubated at lower temperatures were more actively motile than those incubated at the optimal temperature. This finding was reported previously for acetic acid bacteria (Leifson, 1954; Asai et al., 1964). Motile cells showed a single polar flagellum or, occasionally, polar tuft flagella (Fig. 2). Uhlig et al.
(1986) described peritrichous flagella of Acetobacter methanolicus but, in contrast, Urakami et al. (1989) reported no motility of Acidomonas methanolica. All Acidomonas
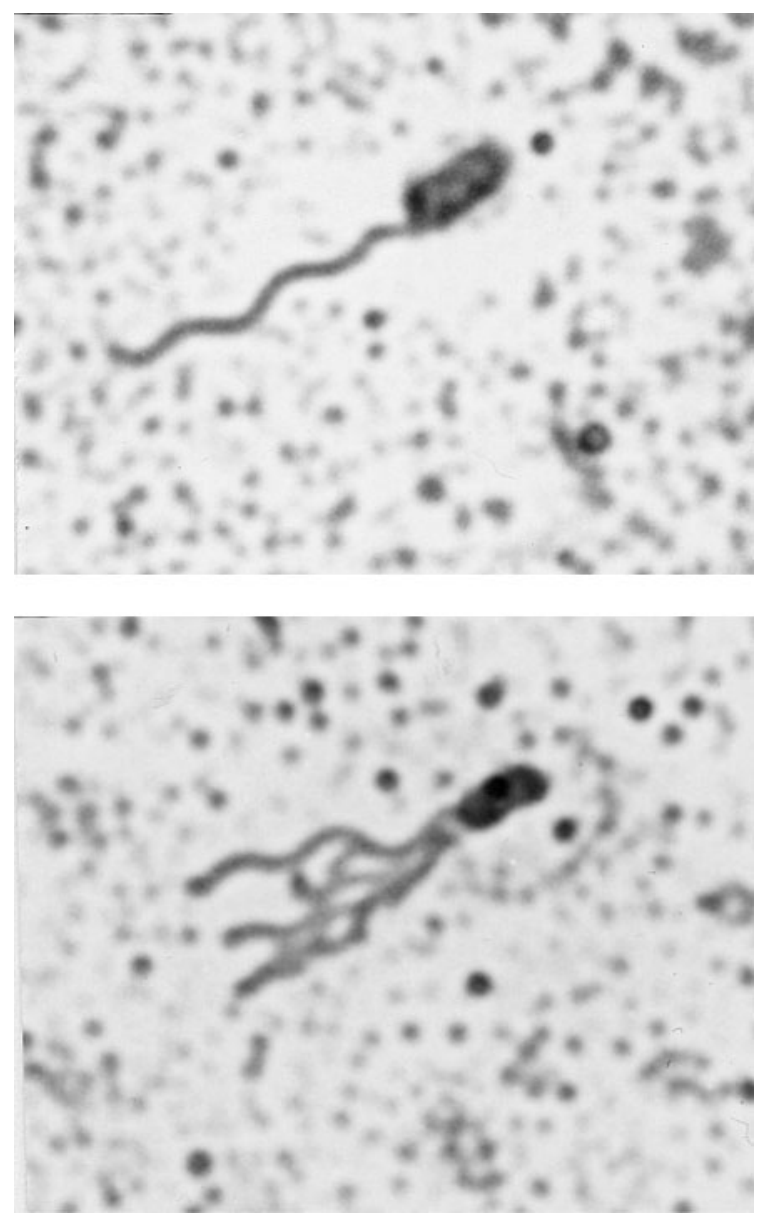

Fig. 2. Flagellation of Acidomonas methanolica LMG 1667 grown on YPM agar at $25^{\circ} \mathrm{C}$. A single polar flagellum (top) and polar tuft flagella (bottom) (found very rarely). 
methanolica strains were unable to grow without pantothenic acid in yeast extract-omitted medium C. This indicated the requirement of pantothenic acid for growth of Acidomonas methanolica, as reported previously (Uhlig et al., 1986; Urakami et al., 1989). In addition, this pointed to the utilization of ammoniacal nitrogen as the sole source of nitrogen by Acidomonas methanolica strains when pantothenic acid was supplied. All strains tested grew on methanol, but glucose was preferred over methanol for growth. The strains produced catalase but not oxidase, as did acetic acid bacteria. Urakami et al. (1985) reported the production of oxidase by Acidomonas methanolica; oxidation of acetate to $\mathrm{CO}_{2}$ and $\mathrm{H}_{2} \mathrm{O}$ by Acidomonas strains was detected readily by the method of Leifson (1954). Oxidation of lactate was not detected clearly by the method of Leifson (1954), but was detected in some strains by the method of Shimwell et al. (1960). Of the 14 strains tested, seven strains oxidized lactate weakly. The strains tested did not produce dihydroxyacetone from glycerol. Uhlig et al. (1986) reported weak ketogenesis from glycerol, but Urakami et al. (1989) did not. No strains tested produced urease. Production of acetic acid from ethanol was determined by GC (Urakami et al., 1989). Acid was produced from D-glucose and eight other sugars and sugar alcohols, but not from D-fructose or 13 other sugars, sugar alcohols or alcohols. Production of acid from D-arabinose and four other sugars and alcohols varied with strains. Of the 14 strains tested, four strains produced acid from methanol and 10 did weakly. Production of acid from sugars and sugar alcohols did not agree with the data of Uhlig et al. (1986) and Urakami et al. (1989). This may be due to medium compositions and procedures. Assimilation of carbon compounds was tested under nutritionally restricted conditions. D-Glucose, D-mannose, glycerol, succinate, ethanol and methanol were assimilated by all strains tested, but D-fructose, L-arabinose, trehalose, maltose, mannitol and inositol were not. Assimilation of D-galactose, D-ribose, D-xylose, citrate, malate, lactate and acetate varied with strains. There were differences in assimilation patterns between the data of Uhlig et al. (1986), Urakami et al. (1989) and the present study. This is due to the methods employed: Uhlig et al. (1986) employed auxanography by using a medium that contained yeast extract and Urakami et al. (1989) employed a liquid medium that contained yeast extract. $\mathrm{pH}$ range for growth was a decisive character to delineate the genus Acidomonas. The 14 strains grew at mostly the same extent at $\mathrm{pH} 3 \cdot 0-8 \cdot 0$. Exceptionally, strains LMG 1735, TS 0101, TS 0128, TS 0143 and TS 0156 grew at $\mathrm{pH} 2 \cdot 5$ and TS 0128 grew at $\mathrm{pH} 8 \cdot 5$. Strain TS 0135 did not grow at $\mathrm{pH} 7 \cdot 5$ or $8 \cdot 0$. Uhlig et al. (1986) reported growth of Acetobacter methanolicus below $\mathrm{pH} 6.5$ and optimally at $\mathrm{pH} 4 \cdot 0$ and $4 \cdot 5$. Urakami et al. (1989) described growth of Acidomonas methanolica between $\mathrm{pH} 2.0$ and 5.5 and no growth at $\mathrm{pH} 1.5$ or 6.0 . The strains tested grew in the presence of $30 \%$ glucose and $0.35 \%$ acetic acid and produced gluconic acid from glucose, but not ketogluconic acids. This finding was reported by Uhlig et al. (1986). This feature will be due to high oxidative activity and complete oxidation of glucose at low concentrations. When high concentrations of glucose are supplied, products other than gluconic acid may accumulate. Major cellular fatty acids were reported to be $\mathrm{C}_{18: 1}$ and $\mathrm{C}_{16: 0}$ and hydroxy acids were 2-hydroxy $\mathrm{C}_{16: 0}$ and 3hydroxy $\mathrm{C}_{16: 0}$ (Urakami \& Komagata, 1987). 2-Hydroxy $\mathrm{C}_{16: 0}$ was found only in Acidomonas strains, compared to other methanol-utilizing bacteria (Urakami \& Komagata, 1987). Other phenotypic characteristics are given in the description of the genus Acidomonas.

The genus Acidomonas is phylogenetically located within the Acetobacteraceae in the $\alpha$-Proteobacteria and shares some characteristics with acetic acid bacteria, such as being catalase-positive and oxidase-negative, production of gluconic acid from glucose and growth in the presence of $0.35 \%$ acetic acid. However, methanol utilization and a unique ecological niche characterize the genus Acidomonas. In addition, the genus Acidomonas should be regarded as acidotolerant but not acidophilic, as strains of Acidomonas methanolica are able to grow at mostly the same extent at $\mathrm{pH} 3 \cdot 0-8 \cdot 0$. Some characteristics of Acidomonas methanolica (Acetobacter methanolicus) differed in the descriptions by Uhlig et al. (1986) and Urakami et al. (1989). These differences were made clear in the present study. Therefore, emendation of the genus Acidomonas and the species Acidomonas methanolica is proposed.

\section{Emended description of Acidomonas Urakami et al. emend. Yamashita, Uchimura and Komagata}

Acidomonas (A.ci.do.mo' nas. Gr. adj. acid acid; Gr. n. monas unit, monad; N.L. fem. n. Acidomonas acidophilic monad).

Cells are Gram-negative, short rods with rounded ends, measuring $0 \cdot 5-0.8 \times 1 \cdot 5-2.0 \mu \mathrm{m}$, and are occasionally up to $4 \mu \mathrm{m}$ in length. Cells occur singly, in pairs or (rarely) in short chains and are either motile by a single polar flagellum or non-motile. Cells with polar tuft flagella are found very rarely. Non-spore-forming. Aerobic. Catalase-positive. Oxidase-negative. Colonies on PYM agar ( $\mathrm{pH} 4.5)$ are shiny, smooth, circular, convex, entire, beige to pink and 1-3 $\mathrm{mm}$ in diameter after 5 days at $30^{\circ} \mathrm{C}$. Pellicles are produced in PYM medium, but they are not real cellulose. Acetic acid is produced from ethanol. Dihydroxyacetone is not produced from glycerol. Acid is produced from L-arabinose, D-xylose, D-ribose, D-galactose, D-mannose, D-glucose, glycerol, n-propanol, n-butanol, 2-methyl propan-1-ol, ethanol and methanol, but not from L-rhamnose, D-fructose, sucrose, maltose, lactose, raffinose, trehalose, D-mannitol, inositol, D-sorbitol, dulcitol or soluble starch. Production of acid from D-arabinose, D-ribose, melibiose and 2-methyl propan-1-ol varies with strains. Methanol, ethanol, D-glucose, D-mannose, glycerol and succinic acid are utilized as sole sources of carbon, but $\mathrm{D}$-fructose, $\mathrm{L}$-arabinose, maltose, trehalose, inositol and D-mannitol are not utilized. Acetate is oxidized, but lactate is not or is only weakly oxidized. Urease-negative. 
Pantothenic acid is an essential requirement for growth. Growth occurs at the same extent between $\mathrm{pH} 3.0$ and $8 \cdot 0$; acidotolerant. Growth occurs at $30^{\circ} \mathrm{C}$, but not at $45^{\circ} \mathrm{C}$. Growth occurs in the presence of $30 \%$ glucose and $0.35 \%$ acetic acid. Gluconic acid is produced from glucose, but 2-keto-, 5-keto- and 2,5-diketogluconic acids do not accumulate in culture media. DNA G + C content ranges from 62 to $63 \mathrm{~mol} \%$. Major cellular fatty acids are $\mathrm{C}_{18: 1}$ and $\mathrm{C}_{16: 0}$ and major hydroxy acids are $2-\mathrm{OH} \mathrm{C}_{16: 0}$ and 3-OH $\mathrm{C}_{16: 0}$. Major ubiquinone is Q-10. Distributed in activated sludge. The type species is Acidomonas methanolica (Uhlig et al.) Urakami et al. emend. Yamashita, Uchimura and Komagata.

\section{Emended description of Acidomonas methanolica Urakami et al. emend. Yamashita, Uchimura and Komagata}

Acidomonas methanolica (me.tha.no'li.ca. N.L. adj. methanolica name of a chemical compound, of methanol).

Basonym: Acetobacter methanolicus Uhlig et al. 1986.

The type strain is IMET $10945^{\mathrm{T}}=\mathrm{DSM} \quad 5432^{\mathrm{T}}=\mathrm{JCM}$ $6891^{\mathrm{T}}=\mathrm{LMG} \quad 1668^{\mathrm{T}}=$ NRIC $\quad 0498^{\mathrm{T}}=\mathrm{MB} 58^{\mathrm{T}} . \quad$ Isolated from a septic methanol/yeast process (Steudel et al., 1980; Uhlig et al., 1986). Characteristics are the same as those given in the description of the genus. Cells are non-motile. DNA G $+\mathrm{C}$ content of the type strain is $62 \mathrm{~mol} \%$.

\section{Acknowledgements}

The authors would like to thank Y. Yamada in their laboratory for his suggestions and the sewage-treatment plants of Ochiai, Morigasaki and Shibaura for permitting the sampling of activated sludge.

\section{References}

Asai, T., lizuka, H. \& Komagata, K. (1964). The flagellation and taxonomy of genera Gluconobacter and Acetobacter with reference to the existence of intermediate strains. J Gen Appl Microbiol 10, 95-126.

Boesch, C., Trček, J., Sievers, M. \& Teuber, M. (1998). Acetobacter intermedius, sp. nov. Syst Appl Microbiol 21, 220-229.

Brosius, J., Dull, T. J., Sleeter, D. D. \& Noller, H. F. (1981). Gene organization and primary structure of a ribosomal RNA operon from Escherichia coli. J Mol Biol 148, 107-127.

Bulygina, E. S., Galchenko, V. F., Govorukhina, N. I., Netrusov, A. I., Nikitin, D. I., Trotsenko, Y. A. \& Chumakov, K. M. (1990). Taxonomic studies on methylotrophic bacteria by $5 \mathrm{~S}$ ribosomal RNA sequencing. J Gen Microbiol 136, 441-446.

Bulygina, E. S., Gulikova, O. M., Dikanskaya, E. M., Netrusov, A. I., Tourova, T. P. \& Chumakov, K. M. (1992). Taxonomic studies of the genera Acidomonas, Acetobacter and Gluconobacter by $5 \mathrm{~S}$ ribosomal RNA sequencing. J Gen Microbiol 138, 2283-2286.

Bulygina, E. S., Chumakov, K. M. \& Netrusov, A. I. (1993). Systematics of Gram-negative methylotrophic bacteria based on $5 \mathrm{~S}$ rRNA sequences. In Microbial Growth on $C_{1}$ Compounds, pp. 275284. Edited by J. C. Murrell \& D. P. Kelley. Andover, UK: Intercept.
Christensen, W. B. (1946). Urea decomposition as a means of differentiating Proteus and paracolon cultures from each other and from Salmonella and Shigella types. J Bacteriol 52, 461-466.

Ezaki, T., Hashimoto, Y. \& Yabuuchi, E. (1989). Fluorometric deoxyribonucleic acid-deoxyribonucleic acid hybridization in microdilution wells as an alternative to membrane filter hybridization in which radioisotopes are used to determine genetic relatedness among bacterial strains. Int J Syst Bacteriol 39, 224-229.

Felsenstein, J. (1985). Confidence limits on phylogenies: an approach using the bootstrap. Evolution 39, 783-791.

Green, P. N. (1993). Overview of the current state of methylotroph taxonomy. In Microbial Growth on $C_{1}$ Compounds, pp. 253-265. Edited by J. C. Murrell \& D. P. Kelley. Andover, UK: Intercept.

Janssens, D., Vereecke, C., Vanhonacker, K. \& 7 other editors (1998). BCCM LMG Catalogue Bacteria 1998. Brussels: Belgian Office for Scientific, Technical and Cultural Affairs.

Kimura, M. (1980). A simple method for estimating evolutionary rates of base substitutions through comparative studies of nucleotide sequences. J Mol Evol 16, 111-120.

Komagata, K. (1990). Systematics of methanol-utilizing bacteria. FEMS Microbiol Rev 87, 291-296.

Komagata, K. \& Suzuki, K. (1987). Lipid and cell wall analysis in bacterial systematics. Methods Microbiol 19, 161-206.

Leifson, E. (1954). The flagellation and taxonomy of species of Acetobacter. Antonie van Leeuwenhoek 20, 102-110.

Lisdiyanti, P., Kawasaki, H., Seki, T., Yamada, Y., Uchimura, T. \& Komagata, K. (2000). Systematic study of the genus Acetobacter with descriptions of Acetobacter indonesiensis sp. nov., Acetobacter tropicalis sp. nov., Acetobacter orleanensis (Henneberg 1906) comb. nov., Acetobacter lovaniensis (Frateur 1950) comb. nov., and Acetobacter estunensis (Carr 1958) comb. nov. J Gen Appl Microbiol 46, 147-165.

Saito, H. \& Miura, K. (1963). Preparation of transforming deoxyribonucleic acid by phenol treatment. Biochim Biophys Acta 72, 619-629.

Saitou, N. \& Nei, M. (1987). The neighbor-joining method: a new method for reconstructing phylogenetic trees. Mol Biol Evol 4, $406-425$.

Shimwell, J. L., Carr, J. G. \& Rhodes, M. E. (1960). Differentiation of Acetomonas and Pseudomonas. J Gen Microbiol 23, 283-286.

Sievers, M., Ludwig, W. \& Teuber, M. (1994). Revival of the species Acetobacter methanolicus (ex Uhlig et al. 1986) nom. rev. Syst Appl Microbiol 17, 352-354.

Steudel, A., Miethe, D. \& Babel, W. (1980). Bakterium MB58, ein methylotrophes "Essigsäurebakterien". Z Allg Mikrobiol 20, 663-672 (in German).

Tamaoka, J. \& Komagata, K. (1984). Determination of DNA base composition by reverse-phase high-performance liquid chromatography. FEMS Microbiol Lett 25, 125-128.

Thompson, J. D., Gibson, T. J., Plewniak, F., Jeanmougin, F. \& Higgins, D. G. (1997). The CLUSTAL_X windows interface: flexible strategies for multiple sequence alignment aided by quality analysis tools. Nucleic Acids Res 25, 4876-4882.

Uhlig, H., Karbaum, K. \& Steudel, A. (1986). Acetobacter methanolicus sp. nov., an acidophilic facultatively methylotrophic bacterium. Int J Syst Bacteriol 36, 317-322.

Urakami, T. \& Komagata, K. (1987). Cellular fatty acid composition with special reference to the existence of hydroxy fatty acids in Gram-negative methanol-, methane-, and methylamine-utilizing bacteria. J Gen Appl Microbiol 33, 135-165.

Urakami, T., Terao, I. \& Nagai, I. (1981). Process for producing bacterial single cell protein from methanol. In Microbial Growth 
on $C_{1}$ Compounds, pp. 349-359. Edited by H. Dalton. London: Heyden.

Urakami, T., Tamaoka, J. \& Komagata, K. (1985). DNA base composition and DNA-DNA homologies of methanol-utilizing bacteria. J Gen Appl Microbiol 31, 243-253.

Urakami, T., Tamaoka, J., Suzuki, K. \& Komagata, K. (1989). Acidomonas gen. nov., incorporating Acetobacter methanolicus as Acidomonas methanolica comb. nov. Int J Syst Bacteriol 39, 50-55.
Yamada, Y., Hoshino, K. \& Ishikawa, T. (1997). The phylogeny of acetic acid bacteria based on the partial sequences of $16 \mathrm{~S}$ ribosomal RNA: the elevation of the subgenus Gluconoacetobacter to the generic level. Biosci Biotechnol Biochem 61, 1244-1251.

Yamada, Y., Katsura, K., Kawasaki, H., Widyastuti, Y., Saono, S., Seki, T., Uchimura, T. \& Komagata, K. (2000). Asaia bogorensis gen. nov., sp. nov., an unusual acetic acid bacterium in the $\alpha$-Proteobacteria. Int J Syst Evol Microbiol 50, 823-829. 